\title{
OCCUPATIONAL STRESS AMONG FARMING PEOPLE
}

\author{
A.S.Ramesh ${ }^{1}$ and C.Madhavi ${ }^{2}$
}

\begin{abstract}
During the last 25 years, agricultural sector has gone through lot of changes and it also found to be one of the potential areas for stress. Greater use of automation technology, more use of organic production, decrease price for agricultural products and new complicated legislations have made the life of farmers more stressful one. In this study an attempt is made to find out the potential factors which cause stress and made the life of farming community more miserable. Results have clearly indicated that the occupation farming leads to stress due to financial, weather, work overload, social interaction and farm hassles. It is inferred that all the selected dimensions are producing either high or medium level of stress to farming people. It is also found that stress due to financial factors is found to be slightly higher than other stresses.
\end{abstract}

Key words: farm stress, financial stresses, weather, farm hassles, social interaction

\section{INTRODUCTION}

Many people have the mindset that farming is a stress free life and rural life is healthier, it helps to establish and maintain close family relationship and financial concerns are less. However this situation has changed over the past years and it is quite interesting that farming is found to be one of the occupations which cause high stress. Stress is our response to anything that threatens our survival. The survival can be physical, emotional, financial, or any kind of survival that's important to human life. When one get excited about something, he feel anticipation, and this helps him get mentally and physically ready for the task. This is called Eustress, and it gives energy. But when one suffer from too much stress, and particularly if it remains over a long period of time, this is called distress. Prolonged distress can result in severe physical and/or emotional problems. In many rural areas, a high percentage of visits to family physicians are due to stress related illnesses. Stress can arise from an opportunity, demand, constraint, threat or challenge when the outcome of the event is both important and uncertain(Lazarus \& Cohen 1977).

In general things that are out of our control, and which last a long period of time, create the most stressful situations. Occupational stress is the negative effect on the individual from the sum of different factors in a work place, which may act as stress. It has been further defined as a perceived imbalance between occupational demands and the individual's ability to perform when the consequences of failure are thought to be important. Beehr and Newman (1978) defined occupational stress as a condition arising from the interaction of people and their jobs and characterized by changes within people that force them to develop from their normal functioning.

However, today farming as an occupation is one of the most dangerous work environment in terms of injuries, diseases due to hazardous situations and different

\footnotetext{
${ }^{1}$ Lecturer, Management Wing, Directorate of Distance education, Annamalai University. India

${ }^{2}$ Professor in Business Administration, Annamalai University, India
} 
physical,biological,chemical,sychological, and sociological factors.

Fetsch and Schultz (1984) have shown that farm and ranch families live and work in one of America's most stressful and dangerous workplaces. In general the very nature of farming is itself may be the cause of some strains for farm families: farming can be an isolating profession since farmers traditionally work long hours, outside, often in bad weather and alone. In a study made by Leslie et al (2002) among Mid-Wales farmers it was found that government policy, financial problems and time pressure are the more stress creating factors. Meludu and Bajowa (2008) compared the stress Coping Strategies of Poultry and Cassava Farmers in Nigeria. Financial, weather, work-related, healthrelated and other people, social and psychological stress are the dimensions of stress taken for the study. The results showed no significant difference in stress coping strategies among the poultry and cassava farmers. It is also suggested that farmers has to be given training to cope with stressful situations. Bruce and Abdullah (1990) developed a measure for farm stress. With the help of the data collected from 362 farmers using factor analysis they come out with the factors life satisfaction, emotional strain, illness frequency, personal finances and time pressures. Among the five factors personal finances and time pressures are found to be the most significant predictors of farm stress.

Many of the factors causing mental and emotional stress are viewed as uncontrollable, and include the weather, disease or pests, commodity prices, input costs, equipment failure, media portrayal of the agricultural industry, government policies and the lack of adequate, affordable, accessible child care. Though tere are many factors cause stress to farming people the following are the factors considered for this study.

\section{Financial Stressors}

The current farm financial crunch is providing a serious source of stress to farm families. Most farmers are caught in the price-cost squeeze and the financial viability of the family farm is under constant threat. Low commodity prices, rising expenses, high debt loads, lack of a regular cash flow, and not enough money for necessities lead to stress among farming community.

\section{Weather Stressors}

Farmers have always had to contend with the unpredictability of the weather. Perhaps one of the reasons why farming is such a stressful occupation is the number of things which have to come together to succeed in farming. Favorable weather is certainly such an element. To produce a good harvest the weather must cooperate in producing a narrow and optimal range of temperatures, sunshine, and moisture.

\section{Work Overload Stressors}

Farm men and women are expected to master a dozen trades. Successful farming requires the skills of businessperson, manager, agronomist, meteorologist, mechanic, laborer, and veterinarian. By adding to these the demands of being a husband or wife and a father or mother, one can get some idea of the complexity of the demands placed on modern farm men and women.

\section{Other People as Stressors}

While interactions with others can provide enrichment and fulfilment, other people can sometimes be also significant sources of stress. Some of the stressors falling in this category are problems in a farm operating agreement with relatives; not seeing enough people; conflicts with spouse; decisions being made without one's personal knowledge; not spending enough time with spouse and family; and not being considered as an important part of the farm business by others. 


\section{Farming Hassles}

These stressors are the dozens of little demands and pressures which are part and parcel of farming and rural life. An equipment breakdown at a peak time, having to travel long distances for goods and services, problems with weeds or insects, sickness in livestock, pressures in keeping up with new technology and products, loss of farm help when most needed, having to use hazardous chemicals, need to learn and adjust to new policies and regulations etc.

\section{Statement of the problem}

Over the past decade the farming community has been experiencing a high level of uncertainty, frustration and challenge. Some of the challenges facing farmers include high fluctuation in price, automation, financial problems etc., today farm families are working in a social and economic environment that is more challenging than ever before, and these pressures can cause a high degree of stress within many farm families. By the very nature of farm work, a lot of our daily lives are not under our control. For instance we have no control over the weather, market prices or interest rates. The equipment can break down at any time. Due to this constant stress that they experience will lead to physical, emotional and behavioural problems. Some ways has to be identified to reduce or remove the stress of farm community.

Agriculture is found to be one of the most prominent sectors in Indian economy. Agriculture and allied sectors like forestry, logging and fishing accounted for $16.6 \%$ of the GDP in 2007 and employed $60 \%$ of the country's population. India is ranked second in the world in terms of agricultural output. India is the largest producer in the world of milk, cashew nuts, coconuts, tea, ginger, turmeric and black pepper. Several studies show a direct connection between a person's level of stress and their potential for an on-the-job injury. Stress is linked with numerous illnesses and diseases such as heart disease, ulcers, hypertension, and infection. Sainath (2007) mentioned in his report that In the five years from 1997 to 2001, there were 78,737 farm suicides recorded in the country. On average, around 15,747 each year. But in just the next four years 2002-05, there were 70,507 . Or a yearly average of 17,627 farm suicides. That is a rise of nearly 1,900 in the yearly averages of the two periods. This means that on average, there has been one farmers' suicide every 30 minutes since 2002. With farming ranking as one of the nation's most deadly industries, farming community found to have high stress level. To reduce occupational stress among farm families is the need of the day. This research explores the ways in which stress affects farming communities and analyzes the impact of demographic factors on farm people perception about stress.

\section{The study aim and objectives}

The broad objective of this study is to find out the factors which cause stress to the farming community.

The partial objectives are:

To study the level of stress farming people experience due to their occupation.

To analyse the impact of gender on financial stressors, weather stressors, work overload stressors, other people as stressors and farm hassles.

To study the influence of farmers' experience on financial stressors, weather stressors, work overload stressors, other people as stressors and farm hassles. 


\section{MATERIALS AND METHODS}

A sample of two hundred farmers from four villages from villupuram district in tamilnadu is selected as sample for this study. Hence this study tries to find out the possible factors which may act as stressors in farming community it is classified as an exploratory research. 50 farmers from each village is selected as sample for this survey by using simple random sampling method. All the selected farmers are commercial farmers and they are having minimum ten years of experience in farming.

The Farm Stress Inventory created by James \& Lilly Walker was used to understand the stress related factors. The authors has classified farm stressors into five factors. Those are

\section{Financial Stressors,}

2. Weather Stressors

3. Work Overload Stressors,

4. Other People as Stressors,

5. Farming Hassles,

The questionnaire consists of 60 statements reflects the five different stress causing factors. The opinion of the farmers is recorded by using a five point scale. The score for each factor the summation of the answers of the twelve statements. If the score is below 24 it is considered as low level of stress, inbetween to 24 to 36 medium level of stress and 36 to 60 as high level of stress due to that particular factor.

As farmers with minimum ten years of experience in farming are selected as sample for this study the age of the respondents vary between 35 to 45 years only. Further it is noted that there is not much deviation in the income level also.
Because of this limitation the analysis is restricted only with two demographic factors gender and experience in farming.

\section{RESULTS AND DISCUSSION}

The level of stress people have due to their occupation may vary from a minimal to a maximal level. It is determined by many of the factors. Table 1 portrays the level of financial stress farmers have on the basis of gender. Out of 200 respondents 118 was found to have high amount of stress and 81 were having moderate level of financial stress. None of the farming people have accepted that he/she is free from financial stress. The ANOVA result shown that there is no significant difference among the farming people perception about financial stress based on gender. So it is concluded that farming community invariably to gender is affected by financial stressors.

Table 2 summarizes farming people perception about weather stressors. Among the male farming people $50.72 \%$ of them have perceived high stress due to weather and the remaining $48.28 \%$ have perceived medium level of stress. Among the female farming people $69.35 \%$ of them have stated that stress due to weather is high and $30.65 \%$ have stated that stress due to weather is medium. At the outset $56.5 \%$ of the farming people have perceive high and $43 \%$ perceive medium level of stress due to weather condition. It is inferred from the one way ANOVA table that there is significant influence by gender over the perception on weather stressors. 
Table 01: Financial stress perceived by the farming people based on gender

\begin{tabular}{|c|c|c|c|c|c|c|c|c|c|}
\hline \multirow{2}{*}{ Gender } & \multicolumn{3}{|c|}{ Financial stressors } & \multirow{2}{*}{ Total } & \multicolumn{5}{|c|}{ ANOVA result } \\
\hline & Low & Medium & High & & Sources & $\begin{array}{l}\text { Sum of } \\
\text { squares }\end{array}$ & $\begin{array}{l}\text { Mean } \\
\text { square }\end{array}$ & $\begin{array}{c}\mathbf{F} \\
\text { value }\end{array}$ & $\begin{array}{c}\mathbf{P} \\
\text { value }\end{array}$ \\
\hline Male & 0 & 63 & 75 & 138 & $\begin{array}{l}\text { Between } \\
\text { groups }\end{array}$ & 55.007 & 55.007 & \multirow{3}{*}{3.006} & \multirow{3}{*}{0.085} \\
\hline Female & 0 & 18 & 43 & 62 & \multirow{2}{*}{$\begin{array}{l}\text { Within } \\
\text { groups }\end{array}$} & \multirow{2}{*}{3623.788} & \multirow{2}{*}{18.302} & & \\
\hline Total & 0 & 81 & 118 & 200 & & & & & \\
\hline
\end{tabular}

Table 02: Weather stressors perceived by the farming people based on gender

\begin{tabular}{|c|c|c|c|c|c|c|c|c|c|}
\hline \multirow[b]{2}{*}{ Gender } & \multicolumn{3}{|c|}{ Stress due to weather } & \multirow[b]{2}{*}{ Total } & \multicolumn{5}{|c|}{ ANOVA result } \\
\hline & Low & Medium & High & & Sources & $\begin{array}{c}\text { Sum of } \\
\text { squares }\end{array}$ & $\begin{array}{l}\text { Mean } \\
\text { square }\end{array}$ & $\begin{array}{c}\mathbf{F} \\
\text { value }\end{array}$ & $\begin{array}{c}\mathbf{P} \\
\text { value }\end{array}$ \\
\hline Male & 1 & 67 & 70 & 138 & $\begin{array}{c}\text { Between } \\
\text { groups }\end{array}$ & 1.603 & 1.603 & \multirow{3}{*}{6.387} & \multirow{3}{*}{0.012} \\
\hline Female & 0 & 19 & 43 & 62 & \multirow{2}{*}{$\begin{array}{l}\text { Within } \\
\text { groups }\end{array}$} & \multirow{2}{*}{49.677} & \multirow{2}{*}{0.251} & & \\
\hline Total & 1 & 86 & 113 & 200 & & & & & \\
\hline
\end{tabular}

Table 3 depicts stress due to work overload on the basis of gender. $42.03 \%$ of the male farming people feel that they have high stress due to over workload, $57.24 \%$ of them feel that they have medium level of stress and only $0.75 \%$ of them ie., only one respondent has given the opinion that his stress is low due to work overload. It is inferred from the one way ANOVA table that there is significant difference between male and female regarding their opinion about work overload stress, since the p-value (0.01) is significant at one percent level.

Table 4 pictures the level of stress farming people face due to social interaction based on gender. Among the 138 male farming people selected for this study $41.30 \%$ have reported that stress arise because of social interaction is high and $57.97 \%$ have reported that they have only medium level of stress due to social interaction. Among the women $56.45 \%$ have reported that they have high level of stress due to social interaction and $43.55 \%$ have reported that they have medium level of stress due to social interaction. The ANOVA result also shows that there is significant difference in the perception for the factor social stressors between male and female farming people.

Table 5 describes the level of stress farming people have due to farm hassles. Majority $56 \%$ have reported that they face high stress due to farm hassles and $43 \%$ have reported that they have medium level of stress and one percent has reported that farm hassles cause low level of stress. The ANOVA result shows that there is significant difference in the opinion between male and female regarding their level of stress caused by farm hassles. 
Table 03: Work overload stressors perceived by the farming people based on gender

\begin{tabular}{|c|c|c|c|c|c|c|c|c|c|}
\hline \multirow{2}{*}{ Gender } & \multicolumn{3}{|c|}{$\begin{array}{l}\text { Stress due to work } \\
\text { overload }\end{array}$} & \multirow{2}{*}{ Total } & \multicolumn{5}{|c|}{ ANOVA result } \\
\hline & Low & Medium & High & & Sources & $\begin{array}{c}\text { Sum of } \\
\text { squares }\end{array}$ & $\begin{array}{l}\text { Mean } \\
\text { square }\end{array}$ & $\begin{array}{c}\mathbf{F} \\
\text { value }\end{array}$ & $\begin{array}{c}\mathbf{P} \\
\text { value }\end{array}$ \\
\hline Male & 1 & 79 & 58 & 138 & $\begin{array}{l}\text { Between } \\
\text { groups }\end{array}$ & 1.709 & 1.709 & \multirow{3}{*}{6.744} & \multirow{3}{*}{0.010} \\
\hline Female & 0 & 24 & 38 & 62 & \multirow{2}{*}{$\begin{array}{l}\text { Within } \\
\text { groups }\end{array}$} & \multirow{2}{*}{50.166} & \multirow{2}{*}{0.253} & & \\
\hline Total & 1 & 103 & 96 & 200 & & & & & \\
\hline
\end{tabular}

Table 04 : Other people stressors perceived by the farming people based on gender

\begin{tabular}{|c|c|c|c|c|c|c|c|c|c|}
\hline \multirow{2}{*}{ Gender } & \multicolumn{3}{|c|}{$\begin{array}{c}\text { Stress due to social } \\
\text { interaction }\end{array}$} & \multirow{2}{*}{ Total } & \multicolumn{5}{|c|}{ ANOVA result } \\
\hline & Low & Medium & High & & Sources & $\begin{array}{c}\text { Sum of } \\
\text { squares }\end{array}$ & $\begin{array}{c}\text { Mean } \\
\text { square }\end{array}$ & $\begin{array}{c}\mathbf{F} \\
\text { value }\end{array}$ & $\begin{array}{c}\mathbf{P} \\
\text { value }\end{array}$ \\
\hline Male & 1 & 80 & 57 & 138 & $\begin{array}{l}\text { Between } \\
\text { groups }\end{array}$ & 1.182 & 1.182 & \multirow{3}{*}{4.774} & \multirow{3}{*}{0.030} \\
\hline Female & 0 & 27 & 35 & 62 & \multirow{2}{*}{$\begin{array}{l}\text { Within } \\
\text { groups }\end{array}$} & \multirow{2}{*}{49.013} & \multirow{2}{*}{0.248} & & \\
\hline Total & 1 & 107 & 92 & 200 & & & & & \\
\hline
\end{tabular}

Table 05: Stress due to farm hassles perceived by the farming people based on gender

\begin{tabular}{|c|c|c|c|c|c|c|c|c|c|}
\hline \multirow{2}{*}{ Gender } & \multicolumn{3}{|c|}{ Farm hassles } & \multirow{2}{*}{ Total } & \multicolumn{5}{|c|}{ ANOVA result } \\
\hline & Low & Medium & High & & Sources & $\begin{array}{c}\text { Sum of } \\
\text { squares }\end{array}$ & $\begin{array}{c}\text { Mean } \\
\text { square }\end{array}$ & $\begin{array}{c}\mathbf{F} \\
\text { value }\end{array}$ & $\begin{array}{c}\mathbf{P} \\
\text { value }\end{array}$ \\
\hline Male & 2 & 65 & 71 & 138 & $\begin{array}{l}\text { Between } \\
\text { groups }\end{array}$ & 1.078 & 1.078 & \multirow{3}{*}{4.224} & \multirow{3}{*}{0.041} \\
\hline Female & 0 & 21 & 41 & 62 & Within & 7 & 5 & & \\
\hline Total & 2 & 86 & 112 & 200 & groups & I & 0.255 & & \\
\hline
\end{tabular}


Table 6 shows the level of financial stress farming people have experienced based on their experience in farming. Among the farming people with below 15 years of experience $29.23 \%$ stated that financial stress is medium and the remaining $70.77 \%$ have stated that financial stress in very high for them. Among the employees with 15-20 years of experience $40 \%$ have reported that financial stress is medium and $60 \%$ of them have reported high level of financial stress. Among the farming people with 21-25 years of experience $44 \%$ have reported high level of financial stress, $54 \%$ have reported medium financial stress and 2\% have reported low financial stress. Among the farming people with more than 25 years of experience $55 \%$ have reported high financial stress and $45 \%$ have reported medium financial stress. No one under below 20 years and above 25 years has reported low financial stress. It is inferred from the one way ANOVA table that there is no significant difference among the perceived financial stress among farming people based on their experience since the p-value $(0.547)$ is not significant at five percent level.
Table 7 portrays stress due to weather based on experience in farming. Among the farming people with the experience below 15 years $70.77 \%$ have stated high stress due to weather and $29.23 \%$ have stated that stress due to weather is medium. Among the farming people with the experience $15-20$ years, $52.31 \%$ have stated stress due to weather is high and $47.69 \%$ state that stress due to weather is medium. People fall in the experience range $21-25$ years $38 \%$ of them have reported high stress due to weather, $60 \%$ medium stress due to weather and only $2 \%$ have stated low stress due to weather conditions. $70 \%$ of the farming people with more than 25 years of experience have stated that they have high stress due to weather and the remaining $30 \%$ have medium stress. It is inferred from the one way ANOVA that there is significant difference among the perception of farming people based on their experience in farming since the p-value is significant at one percent level.

Table 06 : Financial stressors perceived by the farming people based on experience

\begin{tabular}{|c|c|c|c|c|c|c|c|c|c|}
\hline \multirow{2}{*}{$\begin{array}{l}\text { Service } \\
\text { in } \\
\text { farming }\end{array}$} & \multicolumn{3}{|c|}{ Financial stress } & \multirow[b]{2}{*}{ Total } & \multicolumn{5}{|c|}{ ANOVA result } \\
\hline & Low & Medium & High & & Sources & $\begin{array}{l}\text { Sum of } \\
\text { squares }\end{array}$ & $\begin{array}{l}\text { Mean } \\
\text { square }\end{array}$ & $\begin{array}{c}\mathbf{F} \\
\text { value }\end{array}$ & $\begin{array}{c}\mathbf{P} \\
\text { value }\end{array}$ \\
\hline $\begin{array}{l}\text { Below } \\
15 \text { yrs }\end{array}$ & 0 & 19 & 46 & 65 & \multirow{2}{*}{$\begin{array}{c}\text { Between } \\
\text { groups }\end{array}$} & \multirow{2}{*}{39.579} & \multirow{2}{*}{13.193} & \multirow{5}{*}{0.711} & \multirow{5}{*}{0.547} \\
\hline $\begin{array}{c}15-20 \\
\text { yrs }\end{array}$ & 0 & 26 & 39 & 65 & & & & & \\
\hline $\begin{array}{c}21-25 \\
\text { yrs }\end{array}$ & 1 & 27 & 22 & 50 & \multirow{3}{*}{$\begin{array}{l}\text { Within } \\
\text { groups }\end{array}$} & \multirow{3}{*}{3639.216} & \multirow{3}{*}{18.567} & & \\
\hline $\begin{array}{l}\text { Above } \\
25 \mathrm{yrs}\end{array}$ & 0 & 9 & 11 & 20 & & & & & \\
\hline Total & 1 & 81 & 118 & 200 & & & & & \\
\hline
\end{tabular}


Table 07: Weather stressors perceived by the farming people based on experience

\begin{tabular}{|c|c|c|c|c|c|c|c|c|c|}
\hline \multirow[b]{2}{*}{$\begin{array}{c}\text { Service in } \\
\text { farming }\end{array}$} & \multicolumn{3}{|c|}{ Stress due to weather } & \multirow[b]{2}{*}{ Total } & \multicolumn{5}{|c|}{ ANOVA result } \\
\hline & Low & Medium & High & & Sources & $\begin{array}{l}\text { Sum of } \\
\text { squares }\end{array}$ & $\begin{array}{l}\text { Mean } \\
\text { square }\end{array}$ & $\begin{array}{c}\mathbf{F} \\
\text { value }\end{array}$ & $\begin{array}{c}\mathbf{P} \\
\text { value }\end{array}$ \\
\hline $\begin{array}{c}\text { Below } 15 \\
\text { yrs }\end{array}$ & 0 & 19 & 46 & 65 & $\begin{array}{l}\text { Between } \\
\text { groups }\end{array}$ & 3.898 & 1.299 & & \\
\hline $15-20 \mathrm{yrs}$ & 0 & 31 & 34 & 65 & & & & & \\
\hline $21-25$ yrs & 1 & 30 & 19 & 50 & & & & 5376 & 0001 \\
\hline $\begin{array}{c}\text { Above } 25 \\
\text { yrs }\end{array}$ & 0 & 6 & 14 & 20 & $\begin{array}{l}\text { Within } \\
\text { grouns }\end{array}$ & 47.382 & 0.242 & טונ. & 0.001 \\
\hline Total & 1 & 86 & 113 & 200 & & & & & \\
\hline
\end{tabular}

Table 8 pictures the level of stress farming people perceive due work overload based on their experience. Among the farming people with less than 15 years of experience $60 \%$ have reported that stress due to work overload is high and $40 \%$ as medium. Among the farming people with $15-20$ years of experience $49.23 \%$ have reported high stress due to work overload and $50.77 \%$ as medium. It is observed that among the farming people having 21-25 years of experience $32 \%$ of them have reported high stress due to work overload, $66 \%$ have reported medium stress and $2 \%$ have reported low level of stress due to work overload. $45 \%$ of the farming people with more than 25 years of experience have reported high level of stress due to work overload and the remaining 55\% have reported medium level of stress due to work overload. The ANOVA value from the table shows that there is significant difference in the opinion among farming people for work overload stressors based on their experience.

Table 9 summarizes the stress perceived by the farming people due to social interaction based on their experience in farming. Among the farming people with below 15 years of experience $73.85 \%$ have rated that they are having high stress due to social interaction and $26.15 \%$ have reported that they are having medium stress due to social interaction. It is observed that in farming people with 1520 years of experience $53.85 \%$ have stated that they face high stress in social interaction and the remaining $46.15 \%$ have medium stress due to social interaction. Among the farming people with above 25 years of experience $65 \%$ face high stress due to other people and the remaining $35 \%$ face medium stress due to social interaction. It is inferred from the one way ANOVA that there is significant difference among the farming people perception about stress due to social interaction based on their experience since the p-value (0.005) is significant at one percent level. 
Table 08: Work overload stressors perceived by the farming people based on experience

\begin{tabular}{|c|c|c|c|c|c|c|c|c|c|}
\hline \multirow{2}{*}{$\begin{array}{l}\text { Service in } \\
\text { farming }\end{array}$} & \multicolumn{3}{|c|}{$\begin{array}{c}\text { Stress due to work } \\
\text { overload }\end{array}$} & \multirow{2}{*}{ Total } & \multicolumn{5}{|c|}{ ANOVA result } \\
\hline & Low & Medium & High & & Sources & $\begin{array}{c}\text { Sum of } \\
\text { squares }\end{array}$ & $\begin{array}{l}\text { Mean } \\
\text { square }\end{array}$ & $\begin{array}{c}\mathbf{F} \\
\text { value }\end{array}$ & $\begin{array}{c}\mathbf{P} \\
\text { value }\end{array}$ \\
\hline $\begin{array}{c}\text { Below } 15 \\
\text { yrs } \\
\end{array}$ & 0 & 26 & 39 & 65 & \multirow[t]{2}{*}{$\begin{array}{c}\text { Between } \\
\text { groups }\end{array}$} & \multirow{2}{*}{2.579} & \multirow{2}{*}{0.860} & \multirow{5}{*}{3.418} & \multirow{5}{*}{0.018} \\
\hline $15-20 \mathrm{yrs}$ & 0 & 33 & 32 & 65 & & & & & \\
\hline $21-25 \mathrm{yrs}$ & 1 & 33 & 16 & 50 & \multirow{3}{*}{$\begin{array}{l}\text { Within } \\
\text { groups }\end{array}$} & \multirow{3}{*}{49.296} & \multirow{3}{*}{0.252} & & \\
\hline $\begin{array}{c}\text { Above } 25 \\
\text { yrs }\end{array}$ & 0 & 11 & 9 & 20 & & & & & \\
\hline Total & 1 & 103 & 96 & 200 & & & & & \\
\hline
\end{tabular}

Table 09: Other people stressors perceived by the farming people based on experience

\begin{tabular}{|c|c|c|c|c|c|c|c|c|c|}
\hline \multirow{2}{*}{$\begin{array}{l}\text { Service in } \\
\text { farming }\end{array}$} & \multicolumn{3}{|c|}{$\begin{array}{c}\text { Stress due to social } \\
\text { interaction }\end{array}$} & \multirow{2}{*}{ Total } & \multicolumn{5}{|c|}{ ANOVA result } \\
\hline & Low & Medium & High & & Sources & $\begin{array}{c}\text { Sum of } \\
\text { squares }\end{array}$ & $\begin{array}{l}\text { Mean } \\
\text { square }\end{array}$ & $\begin{array}{c}\mathbf{F} \\
\text { value }\end{array}$ & $\begin{array}{c}\mathbf{P} \\
\text { value }\end{array}$ \\
\hline $\begin{array}{c}\text { Below } 15 \\
\text { yrs } \\
\end{array}$ & 0 & 17 & 48 & 65 & \multirow{2}{*}{$\begin{array}{l}\text { Between } \\
\text { groups }\end{array}$} & \multirow{2}{*}{3.290} & \multirow{2}{*}{1.097} & \multirow{5}{*}{4.450} & \multirow{5}{*}{0.005} \\
\hline $15-20 \mathrm{yrs}$ & 0 & 30 & 35 & 65 & & & & & \\
\hline $21-25 \mathrm{yrs}$ & 1 & 25 & 24 & 50 & \multirow{3}{*}{$\begin{array}{l}\text { Within } \\
\text { groups }\end{array}$} & \multirow{3}{*}{48.305} & \multirow{3}{*}{0.246} & & \\
\hline $\begin{array}{c}\text { Above } 25 \\
\text { yrs } \\
\end{array}$ & 0 & 7 & 13 & 20 & & & & & \\
\hline Total & 1 & 79 & 120 & 200 & & & & & \\
\hline
\end{tabular}

Table 10 summarizes the stress perceived by farming people by farm hassles. Among the farming people with less than 15 years of experience $56.92 \%$ have reported that the level of stress caused by farm hassles is high and $43.08 \%$ as medium. Among the farming people with
15-20 years of experience $49.23 \%$ have reported farm hassles produce high stress and $50.77 \%$ have stated that stress produced by farm hassles as medium.

It is observed that among the farming people having 21-25 years of experience 
$26 \%$ of them have reported high stress due to farm hassles, $72 \%$ have reported medium stress and 2\% have reported low level of stress due to farm hassles. $50 \%$ of the farming people with more than 25 years of experience have reported high level of stress due to farm hassles and the remaining 55\% have reported medium level of stress.
The ANOVA value from the table shows that there is no significant difference in the opinion among farming people for the level of stress they experience due to farm hassles based on their experience.

\section{Table 10: Stress due to farm hassles perceived by the farming people based on experience}

\begin{tabular}{|c|c|c|c|c|c|c|c|c|c|}
\hline \multirow{2}{*}{$\begin{array}{c}\text { Service in } \\
\text { farming }\end{array}$} & \multicolumn{3}{|c|}{ Farm hassles } & \multirow[b]{2}{*}{ Total } & \multicolumn{5}{|c|}{ ANOVA result } \\
\hline & Low & Medium & High & & Sources & $\begin{array}{l}\text { Sum of } \\
\text { squares }\end{array}$ & $\begin{array}{l}\text { Mean } \\
\text { square }\end{array}$ & $\begin{array}{c}\mathbf{F} \\
\text { value }\end{array}$ & $\begin{array}{c}P \\
\text { value }\end{array}$ \\
\hline $\begin{array}{c}\text { Below } 15 \\
\text { yrs }\end{array}$ & 0 & 28 & 37 & 65 & \multirow{2}{*}{$\begin{array}{c}\text { Between } \\
\text { groups }\end{array}$} & \multirow{2}{*}{1.197} & \multirow{2}{*}{0.399} & \multirow{5}{*}{1.495} & \multirow{5}{*}{0.217} \\
\hline $15-20 \mathrm{yrs}$ & 0 & 33 & 32 & 65 & & & & & \\
\hline $21-25$ yrs & 1 & 36 & 13 & 50 & \multirow{3}{*}{$\begin{array}{l}\text { Within } \\
\text { groups }\end{array}$} & \multirow{3}{*}{52.303} & \multirow{3}{*}{0.267} & & \\
\hline $\begin{array}{c}\text { Above } 25 \\
\text { yrs }\end{array}$ & 0 & 10 & 10 & 20 & & & & & \\
\hline Total & 1 & 107 & 92 & 200 & & & & & \\
\hline
\end{tabular}

\section{Suggestions}

Farming practicing nowadays is a stressful occupation. Several factors political changes, global market changes, new legislations and Regulations, environmental factors increase the level of stress farmers are experiencing. To cope with those stresses the farmers should be trained with new mechanisms and approaches.

Psychiatric care and counselling to identify and treat depression among farmers can help them to cope with stress. The government is making some financing available to farmers across India to help some of the pressure off the growing debt problems farmers are experiencing. But still they are facing more financial problems.

Awareness regarding government assistance was fairly low among the farmers. A team of experts who can work with local farmers can gather and analyse the problems so that they will understand their problems clearly and come up with new ways to solve the problems. Awareness programs may be conducted to educate them.

Periodical surveys will be conducted among farmers regarding their problems and need based assistance will be given to them. 


\section{CONCLUSIONS}

From this study it is inferred that all the selected stress causing factors have producing either high or medium level of stress to the farm community. Financial stressors are ranked number one on the most stressful things in farming through out the world and other top farm stressors include work overload, weather etc.,. The same is observed in this present study also.
The higher the level of farm stress, the greater the likelihood that the individual farmer will be showing some of the physical and psychological symptoms of stress. The psychological consequences of excessive stress can lower the efficiency and productivity, prevent the farming people from enjoying the pleasures and happiness of life, make them more prone to farm accidents, and threaten the health and happiness of farm families.

\section{REFERENCES}

Robert J. Fetsch and Carol J. Schultz2002 Anger, Conflict, and Violence Levels: A Comparison of Farm/Ranch with City/Urban Residents, The Forum for Family and Consumer Issues Vol. 7, No. 1

Malmberg, A., S. Simkin, and K. Hawton. 1999. Suicide in farmers. British Journal of Psychiatry 175,pp:103-105.

Fetsch, R.J. 1984. Stress and coping on the farm: A comparison of farmers with nonfarmers. Sociological Abstracts, pp; 53-54, No. S16214.

Graham, M., R. Henjum, and D.R. Freeze. 1990. A study of grief from farm loss. Canadian Journal of Counseling 24(2),pp:136-145.

July 1995 Newsletter from the Centre for Agricultural Medicine - University of Saskatchewan.

Pollock Leslie; Deaville Jennifer; Gilman Alice; willock Joyce; A preliminary study into stress in Welsh farmers Journal of mental health 2002, vol. 11(2), pp: 213221 ( 21 ref.)

N. T. Meludu and O. M. Bajowa (2008) Gender and Stress Coping Strategies of Poultry and Cassava Farmers in Nigeria. Journal of Human Ecology 23(2),pp: 159164.

Bruce J. Eberhardt and Abdullah Pooyan (1990) "Development of the Farm Stress Survey: Factorial Structure, Reliability, and Validity" Educational and Psychological Measurement, Vol. 50( 2), pp:393-402

Beehr T.A and Newman J.E (1978) "Job stress, employee health and organizational effectiveness: A facet analysis, model and literature review" personnel psychology, 31,pp: 665-669.

Lazarus R. and Cohen J.B(1977) "Environment stress" in Altman.I and Wohlwill.J.F, Human behaviour and environment, Vol.2 plenum, New york.

http:www.Wikipedia.com 